\title{
Nicomache (Loxochona) lokii sp. nov. (Annelida: Polychaeta: Maldanidae) from the Loki's Castle vent field: an important structure builder in an Arctic vent system
}

\author{
Jon Anders Kongsrud • Hans Tore Rapp
}

Received: 27 January 2011/Revised: 1 May 2011/Accepted: 7 June 2011/Published online: 15 July 2011

(C) The Author(s) 2011. This article is published with open access at Springerlink.com

\begin{abstract}
The discovery of the Loki's Castle vent field at 2,350 $\mathrm{m}$ depth on the Arctic mid-ocean ridge in 2008 represents the first known black smoker vent system in the Arctic region. Preliminary results on the benthic invertebrates collected at Loki's Castle indicate the presence of an endemic fauna dominated by tube-building polychaetes, melitid amphipods and gastropods. Here, we formally describe and investigate the ecological role of a new maldanid species, Nicomache (Loxochona) lokii sp. nov., a species found to be particularly common and regarded as a keystone species in this vent system. The description of the new species is supplemented with a DNA barcode. The subgenus $N$. (Loxochona) includes at present six nominal species, and the new species described herein is the fourth species associated with reducing habitats. A table with diagnostic characters for all species referred to the subgenus is provided. The new species builds tubes up to a length of $20 \mathrm{~cm}$ or more, tightly fastened to the substratum. Together with other tube-building species, $N$. (L.) lokii sp. nov. form a complex three-dimensional habitat for a number of free-living invertebrates. Based on the
\end{abstract}

\section{J. A. Kongsrud ( $\square)$}

Natural History Collections, Bergen Museum,

University of Bergen, P.O. Box 7800, 5020 Bergen, Norway

e-mail: Jon.kongsrud@bm.uib.no

\section{H. T. Rapp}

Centre for Geobiology, University of Bergen, Allégaten 41, 5007 Bergen, Norway

\section{H. T. Rapp}

Department of Biology, University of Bergen,

P.O. Box 7800, 5020 Bergen, Norway

H. T. Rapp

Uni Environment, Thormøhlensgate 49B, 5020 Bergen, Norway morphology of the foregut, the microbial community in the gut and the stable isotope values found for this species, it is concluded that it acts as a grazer in this vent system.

Keywords Vent fauna $\cdot$ Norwegian Sea $\cdot$ Arctic mid-ocean ridge $\cdot$ Black smokers $\cdot$ Stable isotopes · Sphingomonas

\section{Introduction}

Since the discovery of the TAG hydrothermal vent field on the Atlantic mid-ocean ridge, it has been known that hydrothermal vents are not exclusively on ridges with fast spreading rates. The discovery of the Loki's Castle vent field on the Mohn-Knipovich ridge north of Jan Mayen in the Norwegian Sea in 2008 was the first discovery of a black smoker vent field on an ultra-slow spreading ridge and the first along the Arctic ridge systems (Pedersen et al. 2009,2010 ). The field comprises several active up to $13-\mathrm{m}-$ tall black smoker chimneys at the top of an extensive mound of hydrothermal sulphide deposits at $2,350 \mathrm{~m}$ depth. On the north-eastern flank of the field, there is a sedimentary area with low-temperature diffuse venting and up to 1-m-high barite chimneys (Pedersen et al. 2010).

There has been considerable interest in the nature of an Arctic vent fauna. Previous studies in more shallow waters on the ridge just north of Iceland, including the Kolbeinsey, Grimsey and Jan Mayen vent fields (Fig. 1) have shown that the fauna present mainly consists of shallow and bathyal species from the surrounding waters with few examples of species adapted to reduced habitats (Fricke et al. 1989; Schander et al. 2010). In contrast, exploration of the fauna at Loki's Castle draws a completely different picture of an Arctic vent fauna. All major fauna elements, 


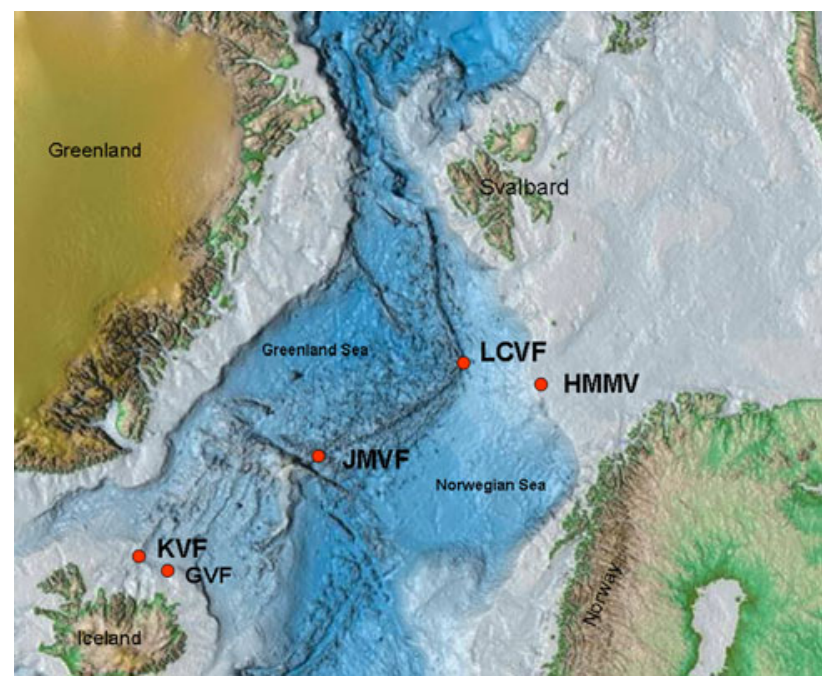

Fig. 1 Map showing the location of the Loki's Castle vent field at $73^{\circ} 33.97^{\prime} \mathrm{N} 08^{\circ} 09.51^{\prime} \mathrm{E}$ in relation to other known vent fields along the Arctic mid-ocean ridge system. Abbreviations: HMMV Haakon Mosby Mud Volcano, KVF Kolbeinsey vent field, GVF Grimsey vent field, JMVF Jan Mayen vent field, $L C V F$ Loki's Castle vent field

including amphipods, polychaetes and gastropods, appear to harbour symbiotic microorganisms (Pedersen et al. 2010; Rapp et al. unpublished data). Preliminary results suggest a relatively high degree of endemism and local adaptation within this fauna with apparent links rather to the Pacific vent faunas rather than to the vent sites further south in the Atlantic (Pedersen et al. 2010).

Polychaetes, especially the Siboglinidae, are known to be important structure builders at hydrothermal vents in the Pacific Ocean as well as in cold seep environments in most oceans (e.g. Van Dover 2000). At Loki's Castle, the typically seep-associated siboglinid Sclerolinum contortum Smirnov, 2000 forms dense aggregations in the sedimentary area on the lee-side of the hydrothermal deposits and within the area of low-temperature venting $\left(\sim 20^{\circ} \mathrm{C}\right)$ and barite chimneys (Pedersen et al. 2010). While these tube worms are normally deeply buried in sediments, threefourth of the tubes are found above the sediment surface at this site, attached to a dense layer of polychaete tubes resting on top of highly anoxic sediments. The main fauna component in this polychaetous mat is a new species of Nicomache (Loxochona). Three out of five species already assigned to this subgenus are known from reduced habitats. $N$. (L.) arwidssoni Blake, 1985 and $N$. (L.) venticola Blake and Hilbig, 1990 are found at vents in the Pacific, while N. (L.) ohtai Miura and Hashimoto, 1991 is found at cold seeps off Japan.

Here, we provide a formal description of the new species of $N$. (Loxochona) and investigate the ecological role of this abundant polychaete in the Loki's Castle vent system.

\section{Materials and methods}

Material was collected from the Loki's Castle vent field during the R/V G. O. Sars cruises BIODEEP in July 2008, H2DEEP in August 2009 and CGB DEEP in July 2010. Benthic samples were taken using the "Bathysaurus" XL remotely operated vehicle (ROV) provided by Argus Remote Systems. Video was acquired using a high-definition camera, and still photos were subsequently captured from the video. During the 2008 cruise, fauna samples were taken from the chimney walls near the base of black smokers as well as in sedimentary areas on the NE slope of the hydrothermal mound. In 2009 and 2010, sampling was more focused within the dense fields of Sclerolinum contortum accompanied with low-temperature barite chimneys. The fauna samples were sorted on board and fixed in either $96 \%$ alcohol or $6 \%$ buffered formaldehyde solution in seawater.

Type material and additional material have been deposited in the Natural History Collections, Bergen Museum, University of Bergen, Norway (ZMBN). The specimens were examined by use of a Leica MZ Stereomicroscope and a Leica DM 6000 B compound microscope. A Canon 20D camera, with MP-E 65-mm and EF $100-\mathrm{mm}$ macro-lenses, has been used for digital photographs of the species. Drawings were prepared in Adobe Photoshop and Adobe Illustrator CS5. SEM micrographs of gut microbes and the structure of the tube wall were made using a ZEISS Supra 55 V SEM on dried and gold/palladium-coated material. Methyl blue was used for staining in order to study and describe the distribution of glandular tissue of the epidermis (Green 1991).

Preparation of samples for stable isotope analyses was performed following standard protocols as described elsewhere (Levin et al. 2009; Pedersen et al. 2010). The $\delta^{13} \mathrm{C}$, $\delta^{15} \mathrm{~N}$ and $\delta^{34} \mathrm{~S}$ stable isotope compositions of the new species were analysed at Institute for Energy Technology (IFE). Approximately $1.0 \mathrm{mg}$ of material was used for the $\mathrm{C}$ and $\mathrm{N}$ analyses and $2.0 \mathrm{mg}$ for the $\mathrm{S}$ analysis. The isotopic measurements were performed using a $\mathrm{Nu}$ Instrument Horizon, isotope ratio mass spectrometer. Results were corrected against the international standards IAEA-N-1 and IAEA-N-2 $\left(\delta^{15} \mathrm{~N}\right)$, USGS-24 $\left(\delta^{13} \mathrm{C}\right)$ and IAEA-S2 $\left(\delta^{34} \mathrm{~S}\right)$. DNA was extracted using the FastDNA ${ }^{\circledR}$ SPIN for Soil Kit following the protocols from the supplier. For barcoding purposes, the mitochondrial cytochrome $c$ oxidase subunit I (COI) gene (the Folmer fragment) was amplified and sequenced following standard protocols (Folmer et al. 1994). The 16SrDNA clone library of endobionts was obtained using the primers B338f (Lane 1991) and B1392r (modified from Amann et al. 1995) and the Strataclone PCR Cloning Kit from Strategene. DOTUR analysis of microbial sequence data was performed to estimate the 
diversity of microbial endobionts (Schloss and Handelsman 2005), and phylogenetic trees (Maximum Likelihood) were constructed using the program ARB.

\section{Results}

Systematics

Family Maldanidae Malmgren, 1867

Subfamily Nicomachinae Arwidsson, 1906

Genus Nicomache Malmgren, 1865
Subgenus Loxochona Arwidsson, 1906

Nicomache (Loxochona) lokii sp. nov. (Figs. 2, 3, 4; Table 1)

Type locality: Loki's Castle vent field, Arctic mid-ocean ridge, $73^{\circ} 33.97^{\prime} \mathrm{N} 08^{\circ} 09.51^{\prime} \mathrm{E}, 2,350 \mathrm{~m}$ depth.

Type material: Type locality from sedimentary area with low-temperature diffuse venting with barite chimneys, R/V "G.O. Sars" H2DEEP cruise 2009 sample ROV-8, 07 August 2009, fixed in 96\% alcohol: Holotype (ZMBN $86266)$ and 10 paratypes, all complete specimens (ZMBN 86267-86269, 86271-86272, 86274, 86276-86279).

Fig. 2 Nicomache (Loxochona) lokii sp. nov., holotype (ZMBN 86266). a Anterior part of body, dorsal view. b Head and setigers 1-2, dorsal view. c The same, lateral view. d Posterior end, lateral view. Scale bars $1.0 \mathrm{~mm}$

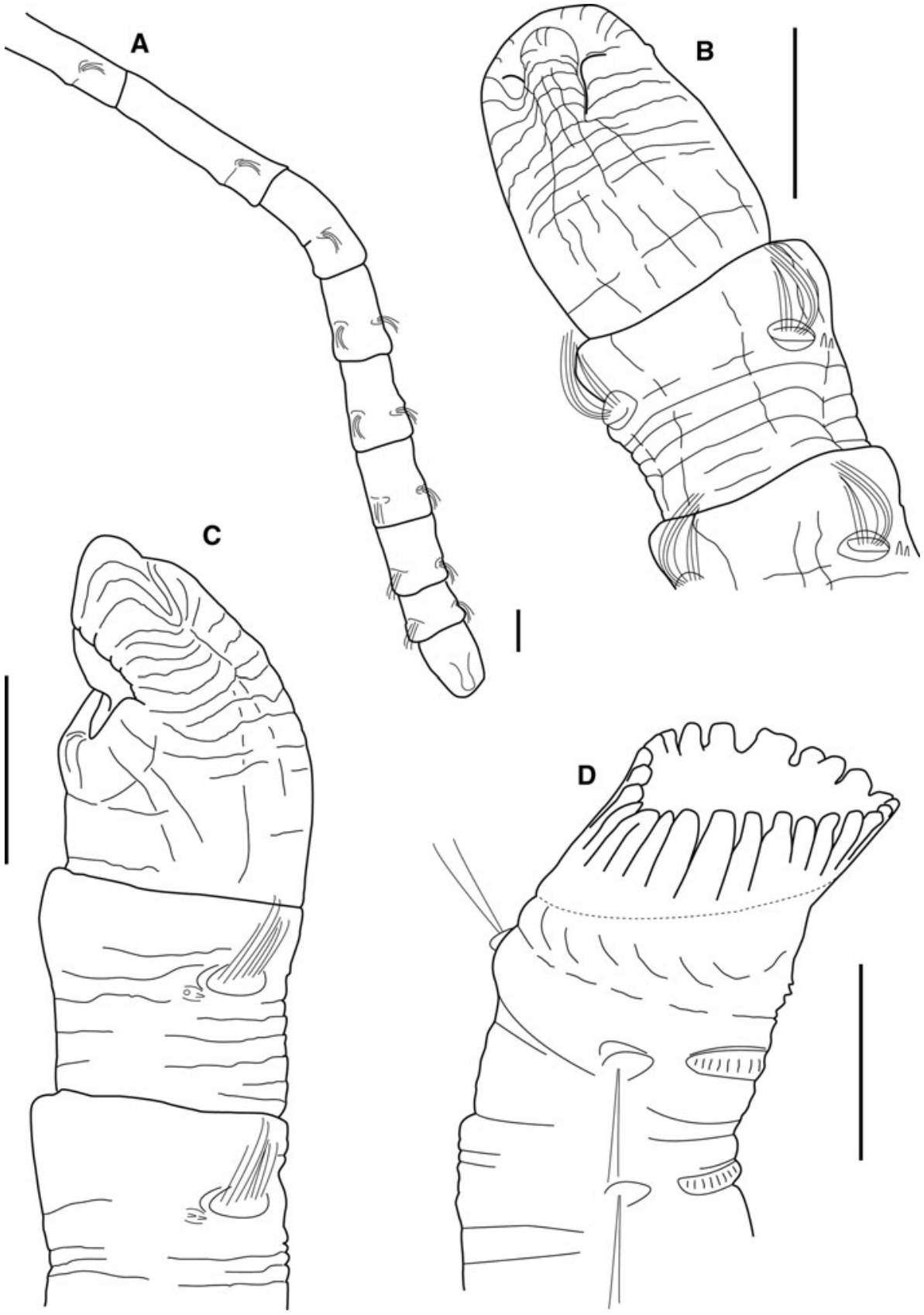




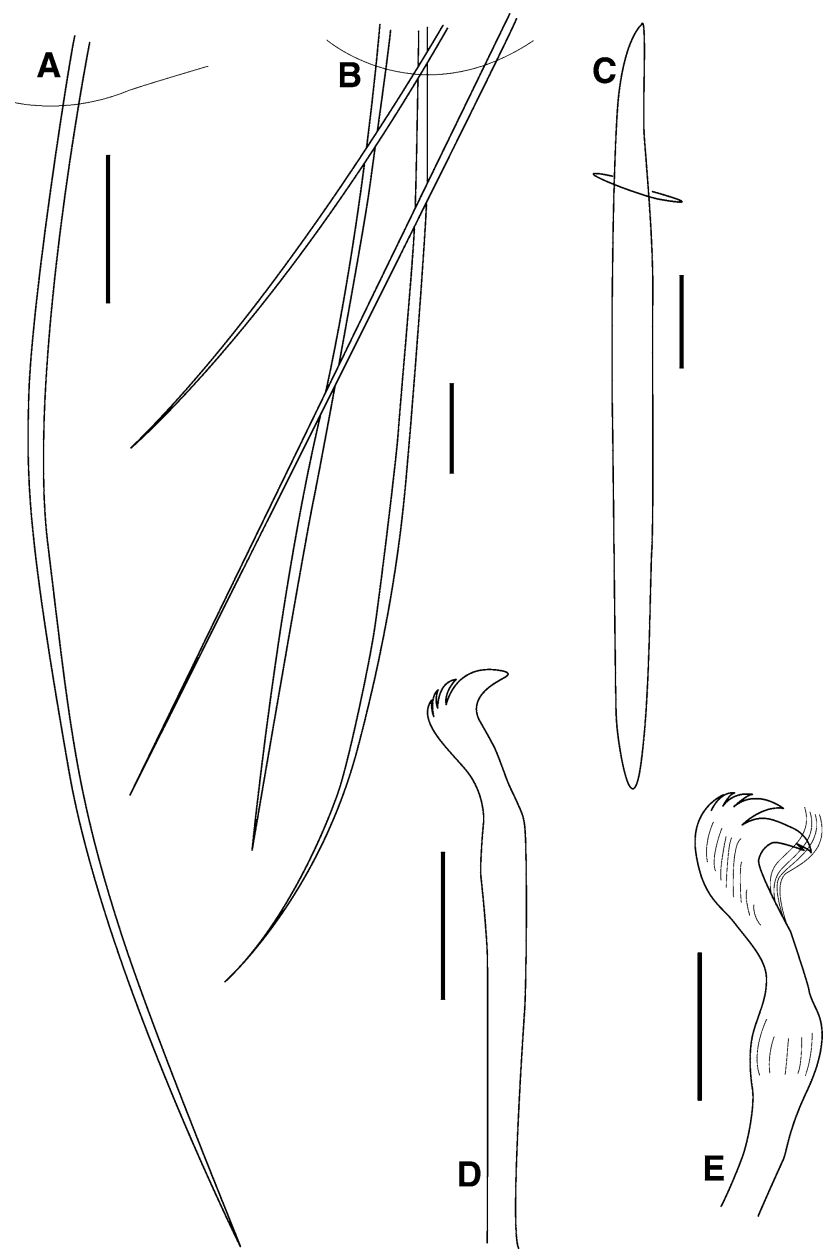

Fig. 3 Nicomache (Loxochona) lokii sp. nov. (ZMBN 86276). a Capillary setae from setiger 1. b Capillary setae from setiger 17 . c Acicular spine from setiger 2. d Rostrate hook from setiger 4 . e Rostrate hook from setiger 15 . Scale bars $50 \mu \mathrm{m}$

Additional material: Type locality from chimney walls near the base of black smokers: R/V "G.O. Sars" BIODEEP cruise 2008, sample ROV-11, 14 July 2008, fixed in $96 \%$ alcohol: 1 spm. (ZMBN 86283); 1 spm. (ZMBN 86284) and 14 spms (ZMBN 86285). Type locality from sedimentary area with low-temperature diffuse venting with barite chimneys: R/V “G.O. Sars" H2DEEP cruise 2009, sample ROV-8, 07 August 2009, fixed in 96\% alcohol: $1 \mathrm{spm}$. (ZMBN 86267); 1 spm. (ZMBN 86270); 2 spms (ZMBN 86273); 4 spms (ZMBN 86275); 10 spms (ZMBN 86280); 4 spms (ZMBN 86281) and $1 \mathrm{spm}$. (ZMBN 86282). R/V "G.O. Sars" CGB DEEP cruise 2010: Sample ROV-04, 15 July 2010 , fixed in $6 \%$ formaldehyde and preserved in $80 \%$ alcohol: 3 spms (ZMBN 86286); 6 spms (ZMBN 86287); 20 spms (ZMBN 86288); several spms in block of tubes (ZMBN 86289). Sample ROV-05, 16 July 2010, fixed in 96\% alcohol: 7 spms (ZMBN 86290). Sample ROV-09, 18 July 2010, fixed in 96\% alcohol: 2 spms (ZMBN 86291).
Diagnosis: A large species, up to $125 \mathrm{~mm}$ long and $1.8 \mathrm{~mm}$ wide, for $22-25$ setigerous segments. Asetous preanal segments absent, Pygidial funnel asymmetric, with anal opening ventrally inside anal funnel. First three setigers with 1-2 (3) straight neuropodial spine(s). From setiger four, neurosetae as rostrate hooks; up to 20 hooks in mid-body setigers. Hooks with maximum four apical teeth above main fang and several subrostral hairs. Spiral notosetae absent. 3-4 pairs of nephridial papillae, starting on setiger 7 or 8 .

Molecular identification: CO1 sequences (DNA barcodes): ZMBN 86269, paratype (Genbank accession nr FR877579) and ZMBN 86270 (Genbank accession nr FR877578)

Description: Body long, cylindrical with asetigerous head, 22-25 setigerous segments and pygidial funnel. Holotype $100 \mathrm{~mm}$ long and $1.2 \mathrm{~mm}$ wide, with 23 setigerous segments. Paratypes $22-125 \mathrm{~mm}$ long and 0.5-1.8 mm wide (Table 1). Prostomium and peristomium fused to form a well-defined head, about 1.5-2 times longer than wide, anteriorly rounded, with wide anterior part (prostomial palpode) (Fig. 2b, c). Cephalic keel well defined, arched. Paired nuchal grooves moderately long, on each side of cephalic keel; posterior part of nuchal grooves parallel, anterior part curving laterally (Fig. 2b). Ocelli not observed. Mouth large, oval, with thick lower lip. Transverse epidermal furrow presents ventrally and laterally slightly posterior to mouth. Dissection of head revealed a foregut with well-developed ventral pharynx and dorsolateral folds.

Anterior seven setigers with swollen anterior margin. Segmental borders distinct in anterior and posterior setigers and indistinct in middle setigers, from about setigers 8-14. Anterior 6 setigers all relatively short, about 1-2 times as long as wide (Fig. 2a). Setiger seven longer, about 2-3 times as long as wide. Length of setigers $8-9$ uncertain due to indistinct segmental borders, but setiger 8 probably short and setiger 9 comparatively long. Setiger 10 and following setigers four times as long as wide or longer. Posterior setigers progressively shorter, with last 1-2 setigers shorter than wide. Parapodia located on anterior half of segments in setigers $1-8$, and near posterior end of setiger 9 and remaining setigers.

Pygidial funnel slightly shorter than wide and asymmetrical, with ventral part longer than dorsal part and somewhat curved outward (Fig. 2d). Posterior rim of pygidium with 20-30 small cirri/papillae (Table 1), exceptionally up to 38 (ZMBN 86280), some of which are bilobed. Mid-ventral cirrus absent. Base of pygidium oblique, with dorsal part of pygidial funnel deeper than ventral part (indicated by stippled line in Fig. 2d). Anus 

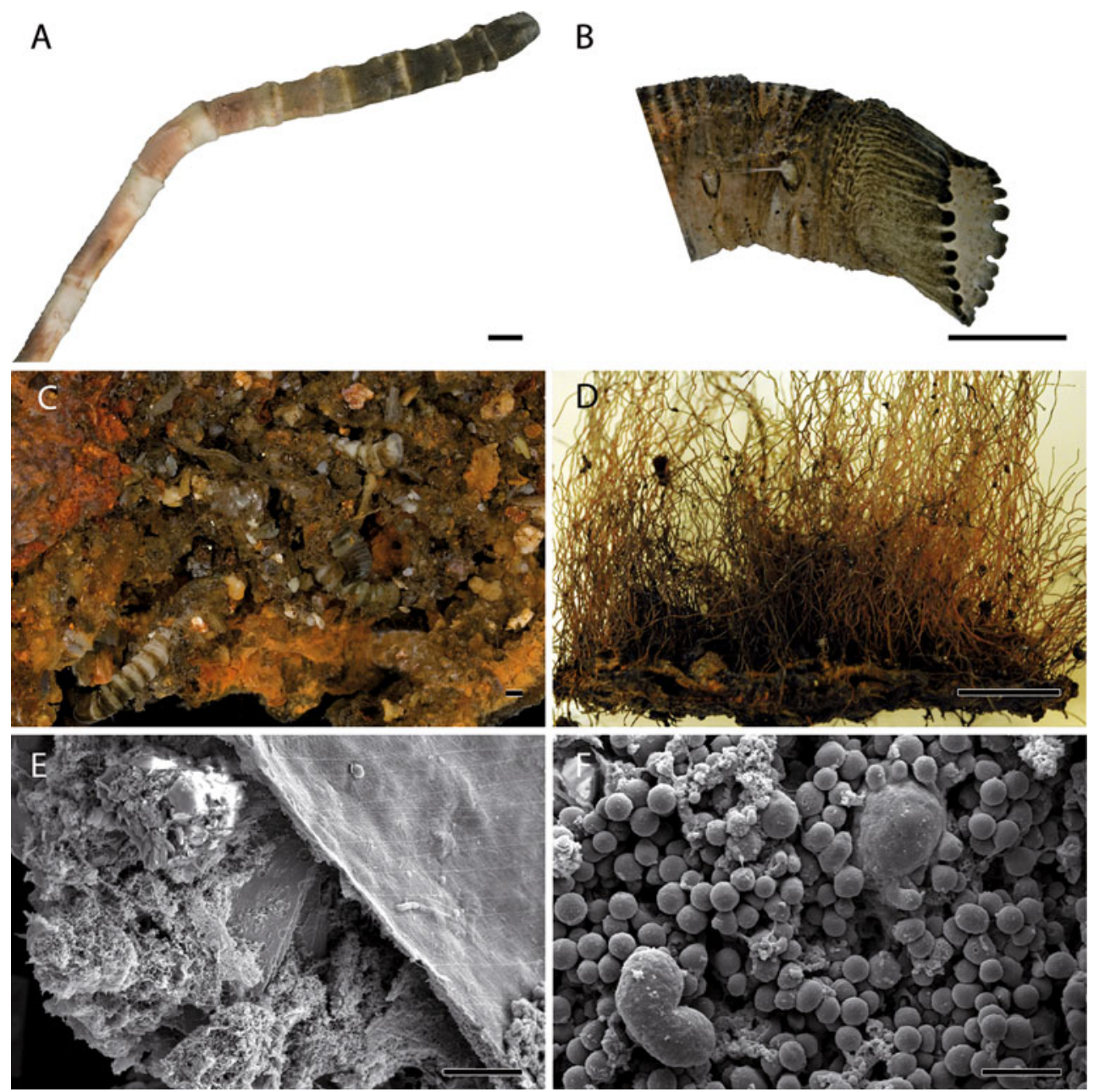

Fig. 4 Nicomache (Loxochona) lokii sp. nov. a Holotype, anterior part of body, dorso-lateral view. b Holotype, posterior part of body, lateral view. c Specimens in ferrous crust on wall of a black smoker. d Nicomache-Pogonophora mat from sedimentary areas with diffuse venting. e SEM micrograph of the tube wall of $N$. (L.) lokii sp. nov.

situated ventrally inside pygidial funnel. Base of anal funnel with longitudinal folds from pygidial rim towards anal opening; each fold with several small papillae. Anal valve absent.

Distribution of glandular tissue characteristic and well stained by methyl blue. Head uniformly stained, except for the nuchal organs. First nine setigers with complete band anteriorly; staining less distinct dorsally in setigers 7-9. Remaining setigers with staining restricted to parapodia and, in posterior setigers, a narrow transverse band dorsally between the parapodia. Pygidial funnel uniformly stained.

All setigers biramous. Setigers 1-3 with comparatively small noto- and neuropodia. Mid-body and posterior setigers with well-developed notopodial lobes and neuropodial tori. Posterior setigers distinctly swollen at level of parapodia. Anterior setigers with notosetae in single row. From setiger 4 , notosetae arranged in double rows. Notosetal rows in dorso-ventral direction in all setigers. All notosetae simple
The outer surface is covered by barite crystals. The tube wall itself is composed of a very fine and regularly woven mesh of fibres. f SEM micrograph of gut microbes in $N$. (L.) lokii sp. nov. Scale bars: a, b $1.0 \mathrm{~mm}$; c $0.5 \mathrm{~mm}$; d $50 \mathrm{~mm}$; e, f $10 \mu \mathrm{m}$

winged capillaries (Fig. 3a, b); capillaries from anterior row shorter and more slender than capillaries from posterior row. Setigers 1-3 with 1-2 (3) straight acicular spines per neuropodium (Fig. 3c). Setiger 4 and following setigers with single vertical row of rostrate hooks (Fig. 3d, e). Number of rostrate hooks varies along body and with body size increasing to a maximum in mid-body setigers and thereafter decreases progressively towards the last setiger. Large specimens with 4-5 hooks in setiger 4 , up to 20 hooks in mid-body setigers, and $8-10$ hooks in the posterior most setiger. Rostrate hooks of setiger 4 with 2-3 apical teeth above the main fang and few, short subrostral fibrils, or fibrils absent (Fig. 3d). Fully developed hooks from setiger 5 , each with four apical teeth above the main fang and several strongly curved subrostral fibrils (Fig. 3e).

Anterior part of body with six internal septa separating setigers 1-7. Three-four pairs of nephridia present, with 
Table 1 Measurements of type specimens of Nicomache (Loxochona) lokii sp. nov.

\begin{tabular}{|c|c|c|c|c|c|c|}
\hline Specimen & Body length (mm) & $\begin{array}{l}\text { Body width } \\
(\mathrm{mm}, \max )\end{array}$ & $\begin{array}{l}\text { Number } \\
\text { of setigers }\end{array}$ & $\begin{array}{l}\text { Number of nephridia (and setigers } \\
\text { with nephridipores) }\end{array}$ & $\begin{array}{l}\text { Number of } \\
\text { anal cirri }\end{array}$ & Sex \\
\hline Holotype (ZMBN 86266) & 100 & 1.2 & 23 & $4(7-10)$ & 27 & Male \\
\hline Paratype (ZMBN 86267) & 96 & 1.8 & 24 & $4(7-10)$ & 28 & Female \\
\hline Paratype (ZMBN 86268) & 22 & 0.5 & 23 & $4(8-11)$ & 20 & \\
\hline Paratype (ZMBN 86269) & 51 & 0.9 & 24 & $4(7-10)$ & 22 & \\
\hline Paratype (ZMBN 86271) & 112 & 1.5 & 22 & $3(7-9)$ & 20 & Female \\
\hline Paratype (ZMBN 86272) & 125 & 1.8 & 24 & $3(7-9)$ & 30 & Male \\
\hline Paratype (ZMBN 86274) & 45 & 0.9 & 23 & $3(7-9)$ & 24 & Male \\
\hline Paratype (ZMBN 86276) & 82 & 1.2 & 22 & $4(7-10)$ & 22 & Male \\
\hline Paratype (ZMBN 86277) & 35 & 0.8 & 23 & $4(7-10)$ & 15 & \\
\hline Paratype (ZMBN 86278) & 43 & 1.0 & 25 & $4(8-11)$ & 23 & \\
\hline Paratype (ZMBN 86279) & 47 & 1.0 & 24 & $4(7-10)$ & 22 & \\
\hline
\end{tabular}

nephridipores located ventrally beneath row of hooks on setigers 7-11 (Table 1).

Pigmentation: Dark-green-to-black pigmentation on head, anterior and posterior setigers and on pygidium. Some specimens with reddish pigmentation on posterior part of setigers 3-7 (Fig. 4a, b).

Tube: Flexible, attached, up to about $200 \mathrm{~mm}$ long, with inner thin transparent organic layer of fine and regular woven mesh of fibres, incrusted with fine-particulate material (Fig. 4e). The tubes of several specimens are often tightly felted into a thick crust (Fig. 4c, d).

Reproduction: Sexes are separate and several females with oocytes in mid-body setigers and males with sperm were observed (Table 1). Oocytes of variable size, discoid, up to about $240 \mu \mathrm{m}$ in diameter. Asexual reproduction by architomy was observed. A specimen divides into two fragments at setiger 12/13, each of which subsequently regenerates the lost parts. The two specimens, after undergoing architomic division, were found in the same tube. Several specimens regenerating posterior or anterior end were also observed separately.

Etymology: The species is named after the Norse god Loki and subsequently the Loki's Castle vent field.

Remarks: The new species is referred to the subgenus N. (Loxochona) based on presence of an asymmetric pygidial funnel, with the base of the funnel being oblique with a ventrally placed anal opening, and the absence of nephridial papillae on setiger 6 (Arwidsson 1906). Some confusion about the number of species referred to the subgenus $N$. (Loxochona) exists in the literature. De Assis et al. (2007a) referred the following six species to the subgenus: N. arwidssoni Blake, 1985; N. quadrispinata Arwidsson, 1906; N. trispinata Arwidsson, 1906 N. canadensis
McIntosh, 1913; N. ohtai Miura and Hashimoto, 1991; and N. venticola Blake and Hilbig, 1990. De Assis et al. (2007b) referred, in addition, two more species, N. personata Johnson, 1901 and N. maculata Arwidsson, 1911, to the subgenus. However, N. canadensis, N. maculata and $N$. personata are all well-documented members of the subgenus N. (Nicomache) Arwidsson, 1906, as they all possess a more or less symmetrical pygidial funnel with a centrally placed anus within the funnel, and nephridial papillae present on setiger 6 (not known for $N$. canadensis) (Johnson 1901; Arwidsson 1911; McIntosh 1913; Arwidsson 1922; Imajima and Shiraki 1982). To summarize, the subgenus N. (Loxochona) comprises at present six species, including the new species described herein (Table 2). N. (L.) lokii sp. nov. differs from N. (L.) ohtai, $N$. (L.) quadrispinata and $N$. (L.) trispinata in the absence of an asetous preanal segment and the absence of spiral notosetae. Further, it differs from $N$. (L.) arwidssoni and $N$. (L.) venticola, both known from hydrothermal vent habitats, in the number of setigerous segments and in maximum number of hooks per setiger. $N$. (L.) venticola differs from both $N$. (L.) arwidssoni and $N$. (L.) lokii sp. nov in the number of acicular spines per neuropodium in setigers $1-3$.

\section{Ecology}

A pronounced difference in size and abundance of $N$. (L.) lokii sp. nov. was observed when comparing samples from the black smoker chimney walls and the low-temperature sedimentary area. On the chimney walls, small specimens (generally smaller than $25 \mathrm{~mm}$ ) form thin crusts of tubes heavily incrusted by ferrous material (Fig. 4c). In the sedimentary Sclerolinum field, large specimens (up to $125 \mathrm{~mm}$ ) form an up to 5-cm-thick mat in the upper part of 


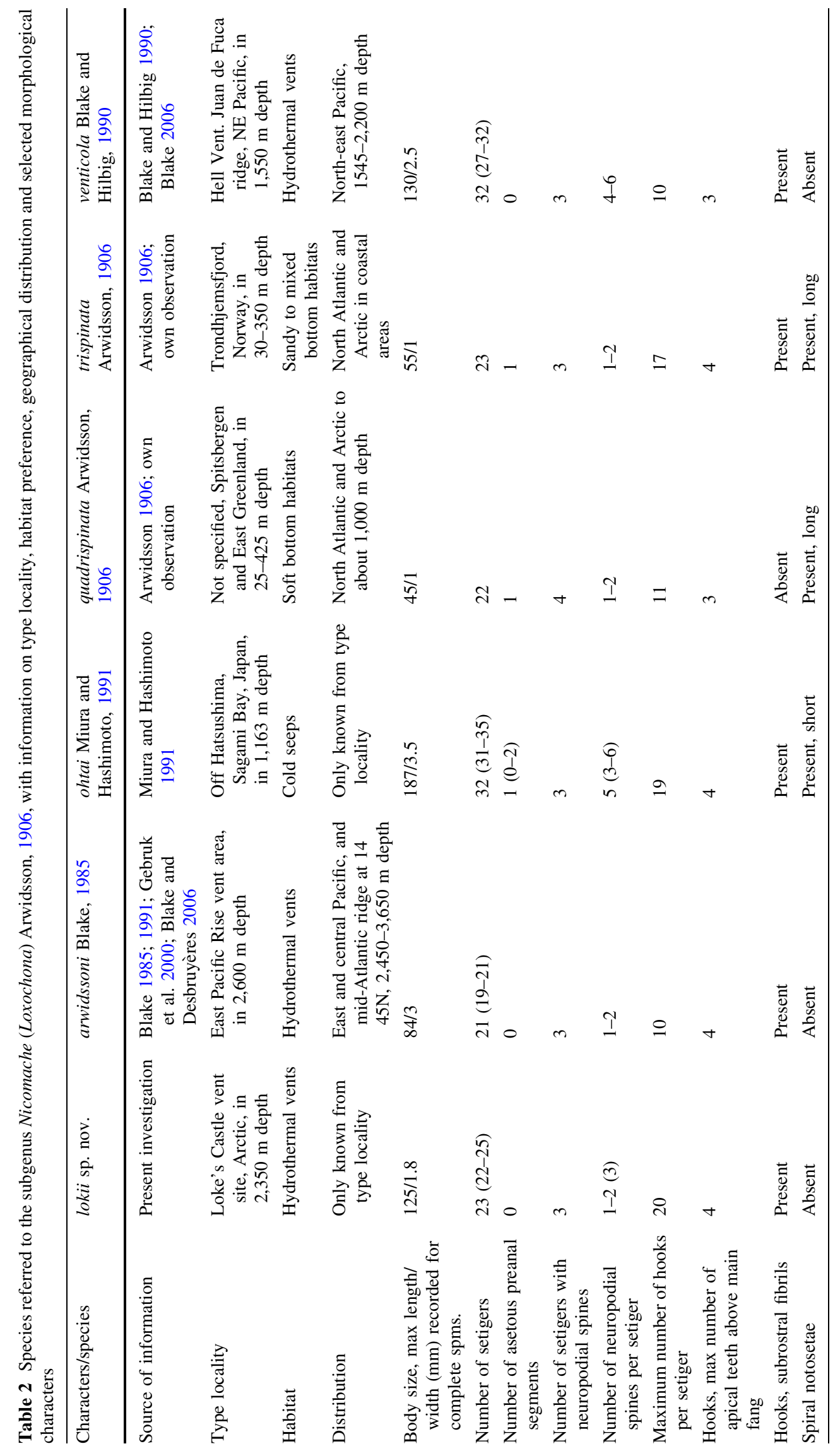


the sediment (Fig. 4d). Just below this mat, the sediment is anoxic, and a minor part of the Sclerolinum tubes penetrate this deep into the sediment. The observed stable isotope values of $\delta^{13} \mathrm{C}=-22.5$ and $\delta^{15} \mathrm{~N}=3.8$ suggest that $N$. (L.) lokei sp. nov. is a grazer, utilizing both the bacterial mats found on the chimney walls and on the sediment surface as well as sinking particles from the water column. This is supported by the morphology of the foregut in $N$. (L.) lokei sp. nov., where the ventral pharynx is well developed and may be used for scraping off food particles from the substrate (Tzetlin and Purschke 2005). However, the sulphur isotope signal $\left(\delta^{34} \mathrm{~S}=11.1\right)$ indicate a trophic relationship with the microbial community (Kennicutt et al. 1992)

SEM micrographs of the inner gut show that the inner wall is densely populated by bacteria (Fig. 4f). From our 16SrDNA clone library of the endobiont community, a total of 53 sequences were obtained. Through DOTUR analysis, we obtained four OTUs with a distance level of $1 \%$. A pronounced dominance of bacteria clustering within the Sphingomonas was found (43 out of 53 sequences), with more than $99 \%$ sequence similarity with Sphingomonas melonis Buonaurio et al., 2002. Further phylogenetic analysis using ARB confirmed these results as all the sequences clustered within the phylum Proteobacteria, where the majority clustered within the alphaproteobacteria and the genus Sphingomonas, a group generally known as decomposers (data not shown).

The mat of polychaete tubes provides both a shelter and substrate for a rich and specialized polychaete assemblage as well as clusters of nematodes and dense populations of gastropods of the genera Pseudosetia and Skenea.

\section{Discussion}

The Norwegian-Greenland Seas are known for hosting a deep water fauna with a species composition that is quite different from the fauna found south of the GreenlandIceland-Faroe ridge (e.g. Svavarsson et al. 1993) and with a high degree of endemism (Gage et al. 2004; Stuart and Rex 2009). Similarities to the Polar Basin indicate a possible connection between the faunas of the northernmost Pacific and the Norwegian-Greenland Seas (Rapp 2004; MacDonald et al. 2010). Preliminary results of the fauna composition at the Loki's Castle vent field indicate that the fauna have developed by local specialization, as well as by migration of fauna from cold seeps and the Pacific (Pedersen et al. 2010). Blake and Hilbig (1990) stated that the genus Nicomache is represented at hydrothermal vents and cold seeps by a group of species lacking the long spiral notosetae characteristic for their shallow-water relatives. The long spiral notosetae are also lacking in N. (L.) lokii sp. nov., suggesting a close relationship with the species associated with reducing habitats in the north Pacific. However, the unexpected record of the Pacific species $N$. (L.) arwidssoni from the Logatchev area on the midAtlantic ridge (Gebruk et al. 2000) clearly indicates the presence of a closely related species also in the Atlantic. A thorough taxonomic and phylogeographical study of material from different vent sites is needed in order to understand the true geographical distribution and relationships between the different species of this group.

The stable isotope data fall within values previously published for maldanids from vent and seep systems (Van Dover 1994; MacAvoy et al. 2005; Bergquist et al. 2007), and in combination with the dominating endobionts as well as the morphology of the foregut with a well-developed ventral pharynx, it is suggested that $N$. (L.) lokii sp. nov. acts as a grazer in the vent system, utilizing the bacterial mats partly mixed with particles sinking from above. In the Loki's Castle vent system, $N$. (L.) lokii thus seems to fill a very similar niche as the specialized bacteriovore $N$. (L.) venticola at the Juan de Fuca ridge in the NE Pacific (Bergquist et al. 2007). The sulphur isotope signal $\left(\delta^{34} \mathrm{~S}=11.1\right)$ indicates a trophic relationship with the microbial community. However, it cannot be concluded whether it is due to sulphur oxidizing endobionts or bacterial mats being the main food source.

The difference in size between individuals growing on chimney walls and in sedimentary areas may be explained by differences in food availability and longevity of the substrate. On the chimney walls, they probably rely on grazing bacterial mats and are easily covered by chimney material as the chimneys grow, while in the more stable sedimentary areas, the $20-\mathrm{cm}$-long Sclerolinum tubes act as efficient sediment traps and thus provide an additional food source for $N$. (L.) lokii sp. nov.

The reproduction biology of $N$. (L.) lokii sp. nov. and ability to carry out asexual reproduction may be one of the explanations for the high abundance of this species in the Loki's Castle Vent community. Although rarely reported in the maldanids, asexual reproduction by architomic division has been reported for Nicomache (Nicomache) minor Arwidsson, 1906 (Tzetlin and Markelova 1985) and Maldane sarsi Malmgren, 1867 (Tzetlin and Markelova 1986; Wrzesinski and Hartmann-Schröder 1994). In all three of these species, arcitomic division seems to be frequent and may contribute significantly to recruitment.

In the genus Nicomache, several species are known to occur in dense populations forming aggregations or galleries of tubes in favourable habitats (e.g. De Assis et al. 2007a; Tzetlin and Markelova 1985). However, N. (L.) lokii sp. nov. seems to be the only vent-species to build large populations, as the two other species, $N$. (L.) arwidssoni and $N$. (L.) venticola, only occur as epifauna on and 
between other vent-organisms (Blake and Desbruyères 2006; Blake 2006). In the Loki's Castle vent community, the densely felted mats of polychaete tubes aid in stabilizing the very soft and anoxic sediments surrounding the vent field and thus provide a stable substrate for a range of invertebrates adapted to reduced habitats. Hence, N. (L.) lokii sp. nov. should be regarded as a keystone species in this Arctic vent system.

Acknowledgments We thank the crew, Rolf Birger Pedersen (cruise leader), scientists and students onboard the R/V G.O. Sars during the cruises 2008-2010 and the operators of the ROV Bathysaurus for their assistance at sea. Ingunn Hindenes Thorseth is thanked for making the SEM images and Solveig Hoem and Louise Lindblom for help with the molecular work. Beate Helle is thanked for doing a great job finalizing the drawings, and Elinor Bartle is acknowledged for improving the language. We thank three reviewers for helpful comments on the manuscript This work has been supported by the NFR through Centre for Geobiology, the Norwegian Academy of Science and Letters and The Norwegian Deep Sea Program (the taxonomy fund) and by the ESF-EUROMARC program through the H2DEEP project.

Open Access This article is distributed under the terms of the Creative Commons Attribution Noncommercial License which permits any noncommercial use, distribution, and reproduction in any medium, provided the original author(s) and source are credited.

\section{References}

Amann R, Ludwig W, Schleifer KH (1995) Phylogenetic identification and in situ detection of individual microbial cells without cultivation. Microbiol Rev 59:143-169

Arwidsson I (1906) Studien über die skandinavischen und arktischen Maldaniden nebst Zusammenstellung der übrigen bisher bekannten Arten dieser Familie. Zool Jahrb Suppl 9:1-308

Arwidsson I (1911) On some Irish Maldanidae. Proc R Ir Acad 29:209-227

Arwidsson I (1922) Systematic notes on some Maldanids. K Sven Vetensk handl 63:1-46

Bergquist DC, Eckner JT, Urcuyo IA, Cordes EE, Houdez S, Macko SA, Fisher CR (2007) Using stable isotopes and quantitative community characteristics to determine a local hydrothermal vent food web. Mar Eco Prog Ser 330:49-65

Blake JA (1985) Polychaeta from the vicinity of deep-sea geothermal vents in the Eastern Pacific. I. Euphrosinidae, Phylodocidae, Hesionidae, Nereididae, Glyceridae, Dorviellidae, Orbinidae and Maldanidae. Bull Biol Soc Wash 6:67-102

Blake JA (1991) A new species of Hesiocaeca (Polychaeta: Hesionidae) from hydrothermal vents at the Mariana Back-Arc Basin with notes on other polychaetes. Proc Biol Soc Wash 104:175-180

Blake JA (2006) Nicomache venticola Blake and Hilbig, 1990. Denisia 18:267

Blake JA, Desbruyéres D (2006) Nicomache arwidssoni Blake, 1985 "bamboo worm". Denisia 18:266

Blake JA, Hilbig B (1990) Polychaeta from the vicinity of deep-sea hydrothermal vents in the eastern Pacific. II. New species and records from the Juan de Fuca and Explorer Ridge systems. Pac Sci 44:219-253
Buonaurio R, Stravato VM, Kosako Y, Fujiwara N, Naka T, Kobayashi K, Cappelli C, Yabuuchi E (2002) Sphingomonas melonis sp. nov., a novel pathogen that causes brown spots on yellow Spanish melon fruits. Int $\mathrm{J}$ Syst Evol Microbiol 52:2081-2087

De Assis JE, Alonso C, Christoffersen ML (2007a) Two new species of Nicomache (Polychaeta: Maldanidae) from the Southwest Atlantic. Zootaxa 1454:27-37

De Assis JE, Samiguel CA, Christoffersen ML (2007b) A catalogue and taxonomic keys of the Subfamily Nicomachinae (Polychaeta: Maldanidae) of the world. Zootaxa 1657:41-55

Folmer O, Black M, Hoeh W, Lutz R, Vrijenhoek R (1994) DNA primers for amplification of mitochondrial cytochrome $\mathrm{c}$ oxidase subunit I from diverse metazoan invertebrates. Mol Mar Biol Biotechnol 3:294-299

Fricke H, Giere O, Stetter K, Alfredsson GA, Kristjansson JK, Stoffers P, Svavarsson J (1989) Hydrothermal vent communities at the shallow subpolar Mid-Atlantic Ridge. Mar Biol 102:425-429

Gage JD, Lambshead PJD, Bishop JDD, Stuart CT, Jones NS (2004) Large-scale biodiversity pattern of Cumacea (Peracarida, Crustacea) in the deep Atlantic. Mar Ecol Prog Ser 277:181-196

Gebruk AV, Chevaldonne P, Shank T, Lutz RA, Vrijenhoek RC (2000) Deep-sea hydrothermal vent communities of the Logatchev area (14 degrees 45' N, Mid-Atlantic Ridge): diverse biotopes and high biomass. J Mar Biol Assoc UK 80:383-393

Green KD (1991) Maldane californiensis, a new species (Polychaeta: Maldanidae) and a review of its relations. Bull Mar Sci 48:214-226

Imajima M, Shiraki Y (1982) Maldanidae (Annelida: Polychaeta) from Japan. Part 1. Bull Natl Sci Mus Tokyo A Zool 8:7-46

Johnson HP (1901) The Polychaeta of the Puget Sound region. Proc Boston Soc Nat Hist 29:381-437

Kennicutt MC, Burke RA, MacDonald IR, Brooks JM, Denoux GJ, Macko SA (1992) Stable isotope partitioning in seep and vent organisms: chemical and ecological significance. Chem Geo (Isot Geosci Section) 101:293-310

Lane DJ (1991) 16S/23S rRNA sequencing. In: Stackenbrandt E, Goodfellow $M$ (eds) Nucleic acid techniques in bacterial systematics. Wiley, New York, pp 115-148

Levin L, Mendoza GF, Kontchick T, Lee R (2009) Macrobenthos community structure and trophic relationships within active and inactive Pacific hydrothermal sediments. Deep-Sea Res II 57:1632-1648

MacAvoy SE, Fisher CR, Carney RS, Macko SA (2005) Nutritional associations among fauna at hydrocarbon seep communities in the Gulf of Mexico. Mar Ecol Prog Ser 292:51-60

MacDonald IR, Bluhm BA, Iken K, Gagaev S, Strong S (2010) Benthic macrofauna and megafauna assemblages in the Arctic deep-sea Canada Basin. Deep-Sea Res II 57:136-152

Malmgren AJ (1865) Nordiska Hafs-Annulater. Ofvers K VetenskAkad Forh 21:181-192

Malmgren AJ (1867) Annulata Polychaeta Spetsbergiae, Groenlandiae, Islandiae et Scandinaviae hactenus cognita. Ofvers $\mathrm{K}$ Vetensk-Akad Forh 24:127-235

McIntosh WC (1913) Notes from the Gatty Marine Laboratory, St. Andrews. No. 34. 4. On the Maldanidae dredged in the Gulf of St. Lawrence, Canada, by Dr. Whiteaves. Ann Mag Nat Hist 8(11):119-228

Miura T, Hashimoto J (1991) Nicomache ohtai, new species (Polychaeta: Maldanidae) collected from the Hatsushima coldseep in Sagami Bay. Proc Biol Soc Wash 104:159-165

Pedersen RB, Thorseth IH, Lilley M, Barriga F, Früh-Green G, Rapp HT, Baumberger T, Flesland K, Jørgensen S (2009) Discovery of the Loki's Castle vent field at the ultra-slow spreading Arctic mid-ocean ridge. Geochim Cosmochim Acta, Suppl S. 73:1008 
Pedersen RB, Rapp HT, Thorseth IH, Lilley M, Barriga F, Baumberger T, Flesland K, Bernasconi-Green G, Flesland K, Jørgensen SL (2010) Discovery of a black smoker field and vent fauna at the Arctic Mid-Ocean Ridge. Nature Comm 1:126. doi: 10.1038/ncomms 1124

Rapp HT (2004) The first record of the genus Leucascus Dendy, 1892 from the Atlantic Ocean, with description of Leucascus lobatus sp. nov. (Porifera, Calcarea) from Greenland. Steenstrupia 28:119-127

Schander C, Rapp HT, Kongsrud JA, Bakken T, Berge J, Cochrane S, Oug E, Byrkjedal I, Cedhagen T, Fosshagen A, Gebruk A, Larsen K, Nygren A, Obst M, Plejel F, Stöhr S, Todt C, Warén A, Handler-Jacobsen S, Kuening R, Levin L, Mikkelsen NT, Petersen KK, Thorseth IH, Pedersen RB (2010) The fauna of the hydrothermal vents on the Mohn Ridge (North Atlantic). Mar Biol Res 6:155-171

Schloss PD, Handelsman J (2005) Introducing DOTUR, a computer program for defining operational taxonomic units and estimating species richness. Appl Environ Microbiol 71:1501-1506

Smirnov RV (2000) Two new species of Pogonophora from the Arctic mud volcano off northwestern Norway. Sarsia 85:141-150

Stuart CT, Rex MA (2009) Bathymetric patterns of deep-sea gastropod species diversity in 10 basins of the Atlantic Ocean and Norwegian Sea. Mar Ecol 30:164-180
Svavarsson J, Strömberg J-O, Brattegard T (1993) The deep-sea Asellota (Isopoda, Crustacea) fauna of the northern seas: species composition, distributional patterns and origin. J Biogeogr 20:537-555

Tzetlin AB, Markelova NP (1985) Some aspects of the distribution and biology of Nicomache minor (Polychaeta: Maldanidae) in the White Sea. Explorations of the Fauna of the Seas 34:136-138 [in Russian]

Tzetlin AB, Markelova NP (1986) Asexual reproduction in the maldanid worm Maldane sarsi (Annelida, Polychaeta). Dokl Acad Nauk SSSR 288:763-765 [in Russian]

Tzetlin A, Purschke G (2005) Pharynx and intestine. In: Bartolomaeus T, Purschke G (eds) Morphology, Molecules, Evolution and Phylogeny in Polychaetes and related Taxa vol 535/536. Hydrobiol pp 199-225

Van Dover C (1994) Microorganisms as food resources at deep-sea hydrothermal vents. Limnol Oceanogr 39:51-57

Van Dover C (2000) The ecology of deep-sea hydrothermal vents. Princeton University Press, Princeton, NJ

Wrzesinski O, Hartmann-Schröder G (1994) Beobachtungen zur vegetativen vermehrung bei Maldane sarsi Malmgren, 1865 (Maldanidae, Polychaeta) aus dem gebiet von Elephant Island (Süd-Shetland-Inseln, Antarktis). Mitt Hambg Zool Mus Inst 91:27-30 